(19) 英国工学者加らみた辰巳用水

THE TATSUMI CANAL VIEWED BY ENGLISH ENGINEERS

\author{
中川武夫宮江伸 ${ }^{* *}$ 中登史 紀 \\ Takeo NAKAGAWA ${ }^{*}$, Shin-ichi MIYAE ${ }^{* *}$, Toshiki NAKA ***
}

\begin{abstract}
The Tatsumi canal of 1632 has been seriously examined by two English engineers K.Walton and A. Brookes on 22 May 1990. Through their examination, it has been pointed out that the Tatsumi canal is an important cultural heritage peculiar to Japan, and an enginnering masterpiece by a genious engineer Hyoshiro Itaya who supervised the construction using the simplest possible instruments and methods elaborated by his careful design and enormous effort. A guiding principle in future management of the Sai river has been proposed. This makes it possible to improve the Sai river in harmony with the ecological system as well as all the product of human activities such as the Tatsumi canal.

KEYWORDS; Canal, River management, Cultural property, Ecology.
\end{abstract}

1. はじめに

辰巳用水（図１参照）は寛永九（１６６３２２）年加賀三代藩主前田利常公が表向きは小松の町人、板屋兵 四郎に命じて金沢城下の防火用水として造らせたものであるが、城内の上水として、またそれまでは涸濠 であった金沢城の㴚に水を満たして徳川氏からの攻撃に備えるのもその目的の一つであったと考えられて いる。兵四郎はこれらの目的を満たすのに必要な水量を確保できるように用水の表面粗度、断面および勾 配を決め、兼六園から東南へ約 $10 \mathrm{~km}$ 離れている犀川上流の雉に取水口を設けた。この工事は総延長約 4 $k m$ の暗渠を含む難工事であったにもかかわらず、わずか一年足らずで完成されたと伝えられている。 その後、約 200 年の間に雉取水口付近の犀川河林が流水の洗掘作用により徐々に低下した結果、用水内

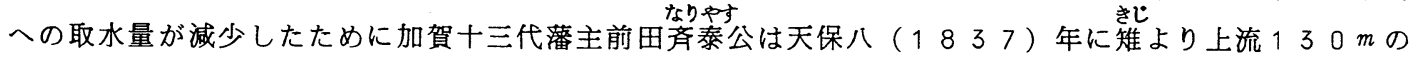
地にある古河口へ取水口の付け替えを命じた。さらに、安政二（１８５５）年には古河口より約５００ m 上流の牪川右岸水衝部で取水に好適な東岩に取水口の付け替えが行われ現在にいたっている。

辰巳用水に関する科学的調査は昭和 42（1967）年頃から江戸時代の特色ある用水技術を今に伝える

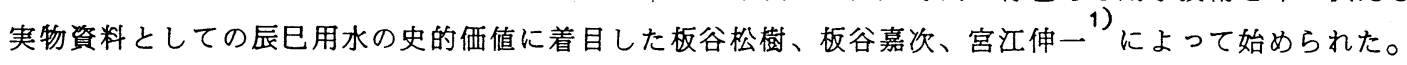
その後の多くの研究を通じて辰巳用水に適用された技術が国内はもとより諸外国の用水技術と比較しても 決してひけをとらない固有の史的価值を有していることが秝々に明らかにされてきた。ところが、昭和57

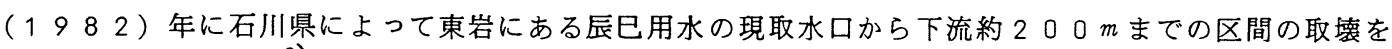
含む辰巳ダム建設計画が提示され、今まさにその本格的な工事が始まろうとしている。

このような辰巳用水の存続にとって極めて危機的な情勢下において辰巳用水に関する二つの論文が国際 誌に公表された。すなわち、最初の論文は辰巳用水に用いられた技術を主題とし「英国土木工学協会誌」

* 金沢工業大学 Kanazawa Institute of Technology, ** 金沢大学 University of Kanazawa, *** 辰巳の文化遺産と自然を守る会 Society for Preserving Cultural Property and Nature at Tatsumi District. 


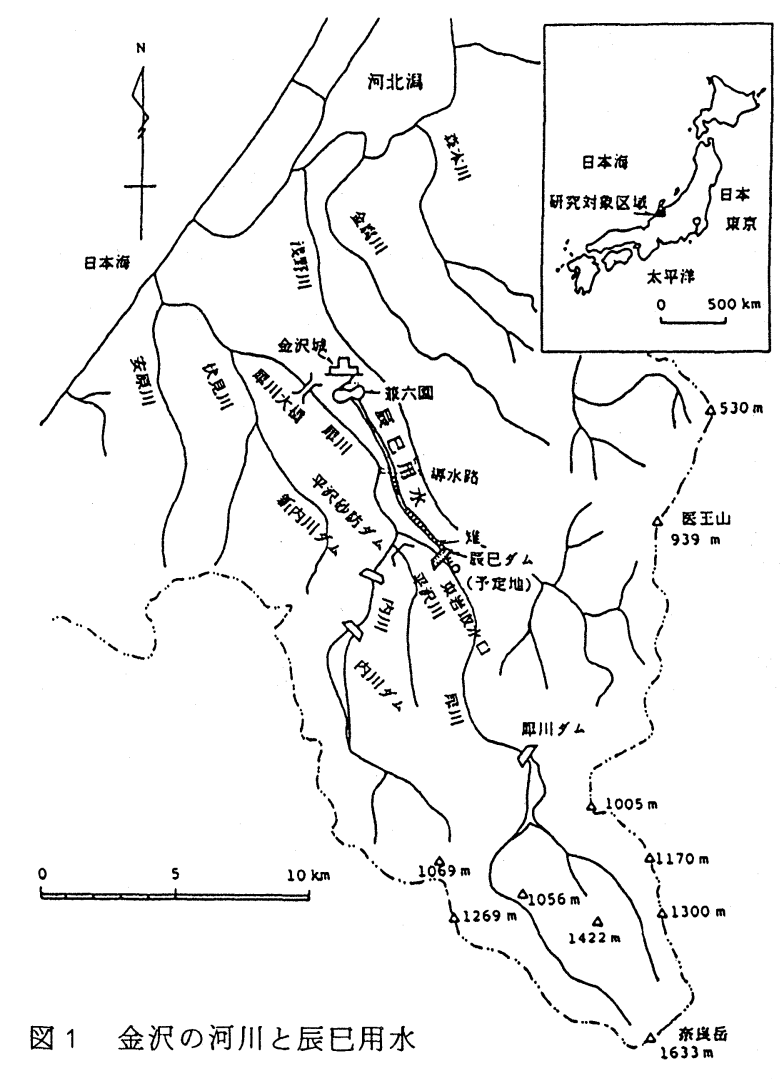

に、二番目の論文 ${ }^{4)}$ は石川県による辰巳ダム計画に対する代替案を主題とし「河川管理」にそれぞれ揭載 され、脣已用水は諸外国においても広く知られるようになった。この結果、脣已用水は世界中の工学者か

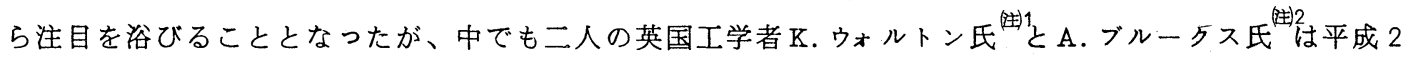
(1990) 年 5 月 21 日から 22 日の間、金沢に滞在し辰巳用水の現地調查にあたった。そして両氏によ る現地調查終了後、「世界からみた辰巳用水」 ${ }^{5)}$ と銘打った講演会並びにパネルディスカッションが金沢市 内で開催された。

本論文の主な目的は二人の英国工学者の辰巳用水に対する見方を紹介し、これらをふまえて辰巳用水の 保存法について指針を呈示することである。

\section{2. 辰巳用水の技術的特色}

本項では辰巳用水に適用された多くの技術の中で特筆に価すると思われる三つを取り上げて紹介するこ ととする。第一番目は図 2 に示したトンネル部の横穴測量法と水路床勾配の決定法である。当時は用水路

(泩1 K. W a Iton (ウォルトン) 氏の略歴：1918年、神戸市に生まれる。ロンドン大学卒。 1945 年一1947年の間、南極探検研究活動に従事し、その後英国海軍大学の講師。 現在、コンサルタント業務に従事。講演題目「工学とは何か」。

(注) 2 A. B r o okes (ブルークス) 氏の略歴：1958年、英国南ヨークシャーに生まれる。サザンプトン大学卒。 河川工学と河川環境との調和をめさす河川形態学の研究に従事。現在、英国河川局勤務。 講演題目「英国の河川環境問題について」。 
掘削に必要な測量をするのに水平と方向のみを知ることができる図了に示した「町見盤」程度のものしか なかったと考えられている。このような簡便な測量器具を用いて、たとえば図 2 に示したように犀川左岸

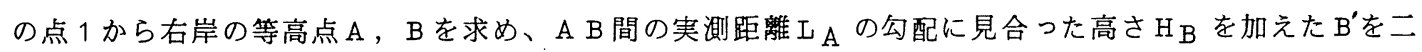
番目の横穴の高さとした。これらの横穴の高さを基準にして水路床高さ並びに水路床勾配を実用上満足す べき精度で決めることに成功した。 ふせてしことわり

第二番目は図 4 に示したような逆サイフォンの原理（伏越の理）を使った兼六園から金沢城への導水法 である。初期の導水管は架筧であったが、そののち松丸太を経て最終的に全て石管に取り替えられた。現在 では残念ながらほとんど跡形もなくなってしまったが、かっては兼六園の霞ヶ池、石川橋、石川門、南御 門を経て二の丸御殿まで辰巳用水の水が送られていた。

第三番目は兼六園から金沢城にいたる導水管路系に用いられた石管接合部からの漏水を防止するために 考案された印篭ばめの技術である。すなわち、突起部やくぼみ部を石管の両端面につくると同時に、互い に隣接する二本の石管の接着部に松ヤ二を塗ることによって漏水が防がれた。また、松中二の接着力を強 めるために石管の両端面を温めてから松中二を塗布したのち、左右から締めつけるという工夫もなされた と层えられている。以上のように辰巳用水の技術的特色は徹底的に工夫をこらすことによって安全かつ確 実な水輸送という工学的目標を物理的原理にのつとつた可能な限り簡便な方法で実現しているところにある。

3. 英国工学者からみた辰巳用水

本項に扔いては辰巳用水に関するパネルディスカッション鸟内容を要約して報告する。なお、パネルデ ィスカッションの内容をより忠実に再現するために対話形式で記述することとする。

質問 1 : 辰巳用水からの受けた印象はどのようなものでしたか?

ウオルトン：私は辰巳用水から非常な感銘を受けました。中でも、特に感銘を受けたのは原始的とも思わ れるほど簡素な道具を用いてあのような精巧な用水が造られたことです。しかも、わずか 10 か月間で完 成されたということに篤きを感じています。また、私は辰巳用水に工学のよい例を見いだしました。

今から 358 年前に板屋兵四郎という工学者が犀川から金沢城に水を引くという困難極まる大土木工事を 人力と非常に簡単な道具のみで実現したのです。と申しますのは、私が先ほどの講演の中で述べましたよ うに費用や道具が足りないというような困難な条件を克服するために自己の能力を最大限に発揮してでき るだけ単純な方法で初期の目的を達成することが工学であると考えているからです。

ブルークス：まず、私が今回金沢を訪れることになった直接の動機は国際的に著名な「河川管理」という 雑誌の先月号に中川・宮江の両氏の連名論文中岀で紹介された屒巳用水に大変興味を覚えたからです。辰巳 用水に関する印象についてはウォルトン氏と全く同感です。私は世界各地にあるさまさまな用水を見たり 多くの人々と用水について議論を重ねてきました。このような私の経験からして辰巳用水が世界の用水の 中でも非常にすばらしいものの一つであることは疑いのないところです。

質問 2 : 辰巳用水をどのように保存していったら良いと思われますか?

ウォルトン：私は日本国民ではありませんから辰巳用水をどのように保存すべきかについて具体的な意見 は申し上げられません。私は日本人であるみなさん自身が辰巳用水をどのように保存していったらよいか を考えるべきだと思います。しかしながら、率直にいえば唇巳用水の清登な水が流れる兼六園の美しい曲 水は保存していくべきであると思います。

質問 3 : 辰巳用水は万難を排して保存されるべき文化財であると思われますか? ウォルトン：私は辰巳用水の保存にあたっては日本以外の国でなされている文化財の保存法も参考にすべ 

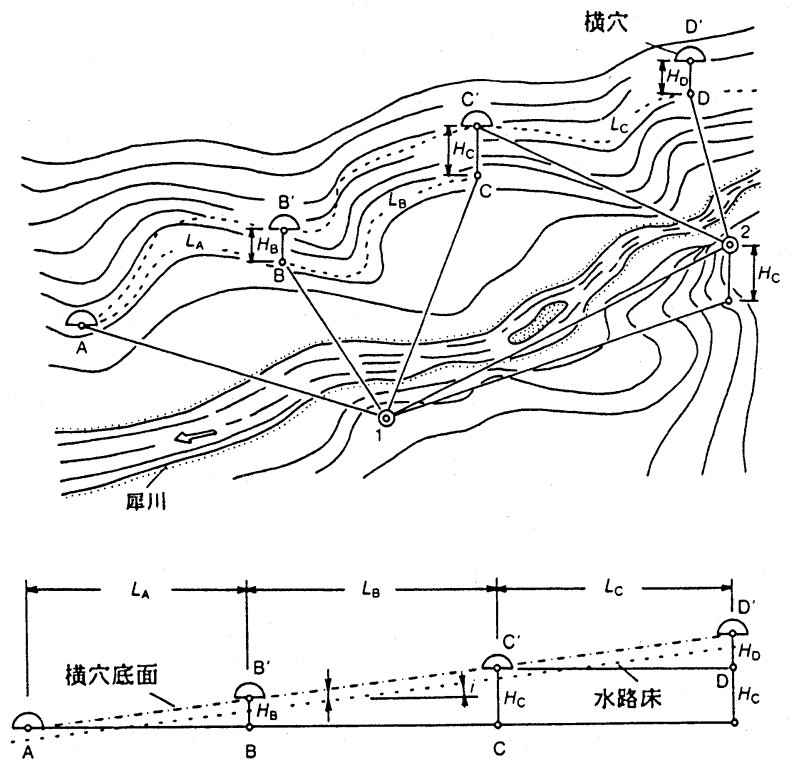

因 2. 横穴の測量法と水路床勾配の決定法

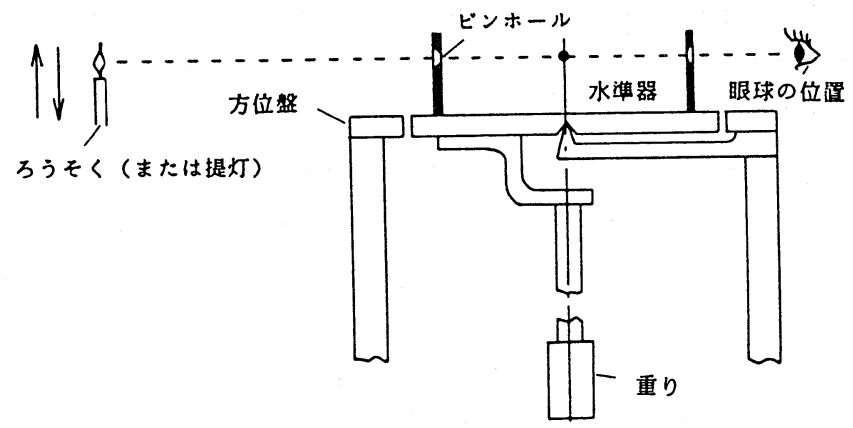

因 3 町見盤原理図

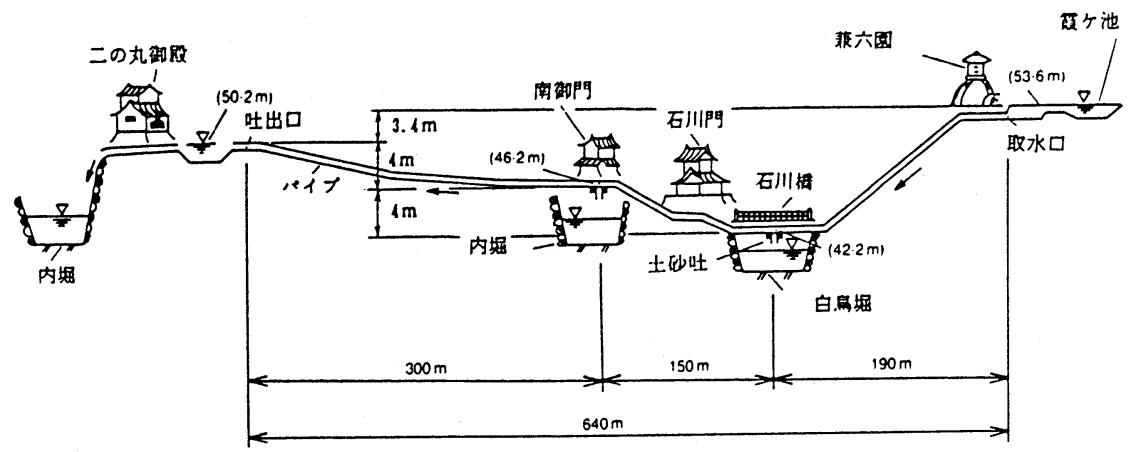

図4兼六園から金沢城内にいたる導水管路系 かっこ内の数字は標高 
きであると思います。たとえば、仏国はアスワンダムを建設する際におびただしい文化財を移動して保存 しています。私がここで申し上げることができるのは辰巳用水が日本の文化財であるということです。 したがって、辰巳用水をどのように保存するかは日本の政府あるいは国民が考えることだと思います。 質問 4. 辰巳用水は日本の国の重要文化財として指定を受ける価值があると思われますか? ウォルトン: 私は「英国土木工学協会誌」に揭載された中川・宮江の両氏による連名論文 ${ }^{3}$ を読んで辰 巳用水に非常な興味を覚えました。そのために、こうして英国からはるばる金沢にやってきたわけです。 したがって、できるだけ多くの人に辰巳用水の本当の姿をみてもらう、あるいは紹介するということが大 事ではないかと思います。ただ、このことと辰巳用水を国の重要文化財に指定すべきかどうかということ とは別問題です。

ブルークス：私は辰巳用水は十分に国の重要文化財としての公的な評価を受けるに足る史跡であると思い ます。

質問 5 : 辰巳用水は上流部のみならず市街地を流れる下流部もきちんと保存しなければならないし、すで に壊されてしまった部分は修復していかなければならないと思います。この点に関してはいかがでしょう か?

ウォルトン：辰巳用水をどのように修復すべきかについては私ははっきりしたことはいえません。しかし ながら、一般論として述べるならば史跡は修復することによって良くなることも、悪くなることもあります。 質問 $6:$ : ブルークス氏の講演の中で英国においては現在、治水工事が川の中やその周辺の生態系に配㦄し ながら、かつできるだけ自然のままの姿を残しながらなされていることを知り非常な感銘を受けた。そこ で質問ですが英国においてこのような治水事業が行われるようになったのはどのような経緯からですか？ ブルークス：かってテームズ川に氾濫があって、テームズ川流域の都市は非常な損害を受けました。そこ で行政側では今後このようなことが起こらないようにしたいと考えました。その時に、いずれにしてもテ 一ムズ川の改修が必要なわけであるから従来のように洪水対策を最優先にするのではなく、この際できる だけ厷範囲から多くの意見を集めて、その生態や環境も考慮に入れながら河川工事を遂行していこうとい うことになったわけです。したがって、市民の圧力でこのようになったわけではなく、行政側がイニシア ティブを取ってきたわけです。また、このような治水事業をすることでその初期の目的をより高いレべル で達成できることもわかっています。四5にただいま申し上げたような治水事業を具現するための新しい 河川管理の一例を示しました。）すなわち、もとの河川流路を全く変更することなく河川の両側の部分の

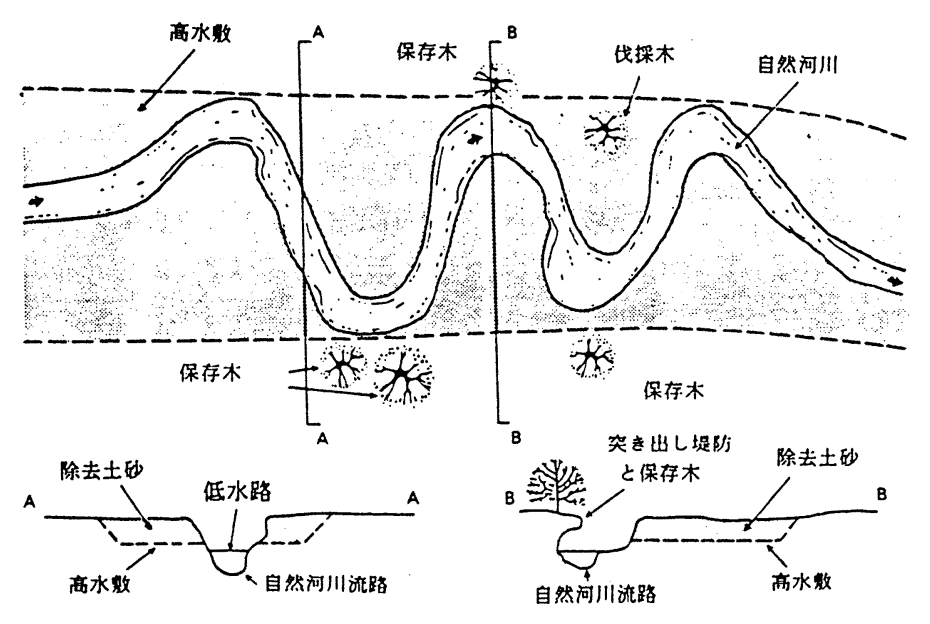

因5.新しい河川管理の例 
土砂を削り取つたのち、流路蛇行範囲の外部に左右それぞれ一本づつの堤防を築き洪水対策とし、同時に 河川環境の保全と両立させることを考えたわけです。このように河川を管理することによってもとの河川生 態系に対する影響が軽隇されるばかりか、河川環境を改善することも可能です。また、河川の両側の部分 の土砂を削り取ったことにより洪水時の通水能力が向上することは明らかです。このほか、過去に人工的 に直線化された河川流路を古い地図などを頼りに復元することによってより安定な河川を再生するような 事業も実施しています。

\section{4. おわりに}

2)

辰巳ダムの建設計画が石川県から公表されて以来、唇巳用水を守るための活動が金沢市民を中心にして 地道に続けられてきた。この活動は我々が祖先から継承した貴重な文化遺産である辰巳用水を適切に保存 して、子子孫孫にわたって末長く伝えていきたいというごく自然の願いから発した純粋なボランティ ア精神に負うところが大である。この活動の一環として著者らは辰巳用水を広く世界の人々に紹介するた めに辰巳用水に関する論文二編 ${ }^{3}$ 文英文で著わしこれらを国際誌の誌面を貸りて公表した。著者らはこれ らの論文が辰巳用水を保存していきたいという多くの人々の悲願を達成するための二粒の種子となって将 来は必ずや結実することを信じている。今回、これらの論文が縁となって K. ウォルトン氏と A. ブルークス氏 が来沢され、新しい辰巳用水に関する見解を示めされたことはこれらの萌芽にほかならないと著者らは考 えている。すなわち、両氏の見解に従えば辰巳用水は日本固有の世界的な文化遺産であると同時に、板屋 兵四郎という天才の努力と工夫によって極限まで単純化された道具と手法で造られた工学上の一大脌作で

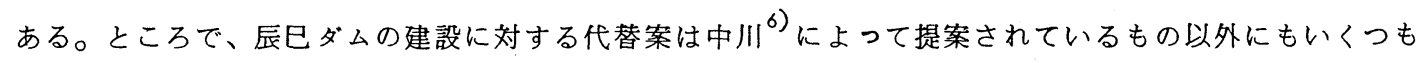
存在することは明らかである。それにもかかわらず、人類にとって貴重な文化遺産である屒巳用水を辰巳 ダム建設の現計画 ${ }^{2)}$ に沿って葬り去るような愚かな行為は決して許されるべきではない。今こそ、板屋兵 四郎の努力と工夫の態度を手本として石川県が計画している唇巳ダム建設に対する代替案を衆知を集めて 考える時である。なお、将来唇巳ダムの代替案を考える際には A. ブルークス氏によって紹介された河 川 (犀川人唇巳用水のような人間の文化活動の所産を含むあらゆる生態系との共生を目さす新しい河川管理 の理念を勘案することが強く望まれる。著者らは一日も早く現在の唇巳ダム建設計画 ${ }^{2)}$ が白紙撤回され、 我国が世界に誇る辰巳用水の現状保存を必要条件とした最適な辰巳ダムの代替案に沿って犀川水系が目標 とされている百年に一度の大洪水に対しても安全となるように整備されることを切望している。

\section{參考文 献}

1）板谷松樹、板谷嘉次、宮江伸一、兼六園全史「辰巳用水」、兼六園全史編集委員会、125-166、 昭和 $51(1976)$ 年1 2月。

2 ) 犀川水系犀川「犀川総合開発事業計画書」展巳ダム、石川県、昭和5 7 (1982) 年8月。

3 ) Nakagawa, T. and Miyae, S. The Tatsumi canal of 1632, Japan Proc. Ins. Civil Engrs, part1, 1143-1165 (1989)。

4 ) Nakagawa, T. and Miyae, S. Management of the Sai river and the Tatsumi Canal, Japan. Regulated Rivers, 5, $183-188$ (1990)

5 )「世界からみた唇巳用水」、英国の二人の工学者による講演会・講演要旨録、唇巳の文化遺産と自然 を守る会、平成 3 年 (1991) 4 月。

6) 中川武夫、文化財保存と国土開発との調和点を模索して、一辰巳用水保存と唇巳夕゙ム建設計画一、 環境システム研究、16、59-64、昭和 63 (1988) 年 8 月。 